\title{
The Difference of Satisfaction Level in BPJS Health Insurance Patient and Non Insurance Patient toward Health Service
}

\author{
Arlina Dewi, Naufal Kurnia Ramadhan \\ Department of Magister Hospital Management, Universitas Muhammadiyah Yogyakarta, Indonesia
}

\begin{tabular}{l}
\hline \hline Article Info \\
\hline Article history: \\
Received Sep 13, 2015 \\
Revised Dec 27, 2015 \\
Accepted Jan 26, 2016 \\
\hline
\end{tabular}

\section{Keyword:}

Health Service

Insurance System

National health insurance

Satisfaction level

Social Security

\begin{abstract}
National Health Insurance (JKN) developed in Indonesia is part of the National Social Insurance System (SJSN). One way to assess the services quality is to measure the patient satisfaction level. This research is a quantitative research with the cross sectional research design. The subjects of this research were the BPJS health insurance patients and non insurance patients with 200 people as the samples. The data was analyzed by the independent t-test, gap analysis, CSI (Customer satisfation index) and IPA (Importance performance analysis). The result showed that significant ( $\rho$ value $>0,05)$ in all dimensions which mean that there is no difference of patient satisfaction level in Social Security Organizing Body (BPJS) participants and non insurance patients toward health services in Negara General Hospital. The biggest satisfaction in non insurance patients is on the Assurance variable $(-1,002)$ and the smallest satisfaction is on the Tangibles variable $(-1,357)$ and the biggest satisfaction of BPJS health insurance patients is on Assurance variable $(-1,085)$ and their smallest satisfaction is on Responsiveness variable $(-1,367)$. The non insurance patients gap is $(-0,217)$ and the BPJS health insurance patients gap is $(-1,206)$, both of them were classified into low satisfaction level. The result of Importance performance analysis value of non insurance patient showed Responsiveness attributes that should be prioritized and improved while in BPJS health patients showed Responsiveness and Reliability attributes that should be prioritized and improved by Negara General Hospital.
\end{abstract}

Copyright (C) 2016 Institute of Advanced Engineering and Science. All rights reserved.

\section{Corresponding Author:}

Arlina Dewi,

Department of Magister Hospital Management,

Universitas Muhammadiyah Yogyakarta, Indonesia.

Email: dewikoen@yahoo.com

\section{INTRODUCTION}

Health is the basic need of every human being to have a good living, productive, and to be able to compete in improving their living standard. Developing countries face multiple health challenges. Besides the diseases common to all countries, such as diabetes and cancer, they face an additional disease burden related to their geography and poverty, including tropical diseases, such as malaria, dengue fever, schistosomiasis and waterborne diseases, due to unclean drinking water, respiratory diseases and others [1].

Health status of the Indonesian people has improved significantly but slowly over the last two decades. Many factors affected the slow improvement of health status in Indonesia such as: low education, low income, difficult geographical access, cultural barriers, and low health expenditures [2].

Most developing countries in the region need additional financial resources to ensure necessary access and coverage for their population. Social health insurance is one of the options to increase financial resources for health through equitable and affordable contributions. Many experts also agree that social health insurance has a big potential to translate out-of-pocket payments to prepayment [3]. National Health 
Insurance (JKN) developed in Indonesia is a part of National Social Insurance system (SJSN) organized through the mechanism of Social Health Insurance that is required (mandatory) [4].

Patient satisfaction is the important thing in the implementation of health services. The degree of patient satisfaction can be used as a means of assessing the quality of health care. It reflects the ability of the provider to meet the patients needs [5]. Satisfaction has been shown to predict important health related behaviour such as adhering to treatment recommendations and maintaining continuity of care [6].

\section{RESEARCH METHOD}

This research is a quantitative research with the cross sectional research design. The subjects of this research were the patient from Social Security Organizing Body (BPJS) participant and non insurance patients that get inpatient care in Negara General Hospital by 200 people as the sample. The convenience sampling in form of questionnaire used in getting the sample, the collected data tested with the Independent $\mathrm{T}$ test and gap analysis, CSI (Customer satisfaction index) and IPA (Importance performance analysis) are used to assess the quality services.

\section{RESULTS AND ANALYSIS}

The study was conducted on May 2014 to October 2014 in Negara General Hospital located in Jembrana regency, Negara district Bali. The total samples are 200 people, 100 people as the non insurance patients and the rest of them as the BPJS health insurance patients.

Table 1. The Difference Patient Satisfaction according to Services Quality Dimension

\begin{tabular}{ccc}
\hline No. & Satisfaction Dimension & P value \\
\hline 1. & Tangible & 0,479 \\
2. & Reliable & 0,603 \\
3. & Responsiveness & 0,522 \\
4. & Assurance & 0,159 \\
5. & Emphaty & 0,860 \\
\hline
\end{tabular}

Table 1 shows the result of the independent t-test obtained $\rho$ value $>0,05$ in all dimensions which mean there is no difference of patient satisfaction level in BPJS ( health participants and non insurance patients who obtain health services in Negara General Hospital. There is no significant differences the other research entitled The Difference Of Patients Satisfaction Between The Askes Patients and The Non Askes Patients in Receiving The Service Quality in Class II Installation Room of Panembahan Senopati Bantul Hospital, obtained $\mathrm{p}$ value $>0,05$ which mean no significant difference between the satisfaction level BPJS patient and non BPJS patient in receiving the service quality [7].

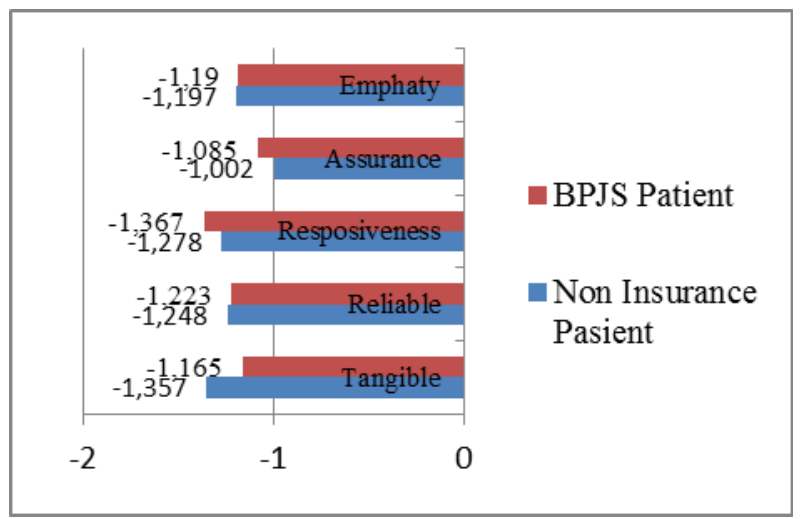

Figure 1. The comparison of mean score in each dimention

From the collected data, it can be seen from Figure 1 that the most satisfying variable for both non insurance patient and BPJS health insurance patient is similar, it is assurance variable, which score is $(-1.002)$ 
at non insurance patient and $(-1,085)$ at BPJS health insurance patient. Although this score is categorized into low, but it is still the best among the other variables. If it is compared with a research which title about an analysis of service quality influence toward patient's satisfaction at community health centers Depok 1 in Sleman, there are differences where the variable that has the highest satisfaction level or with the smallest gap is Responsiveness $(-0,42)$ and the variable that has the smallest satisfaction level or with the biggest gap is Emphaty $(-0,65)[8]$.

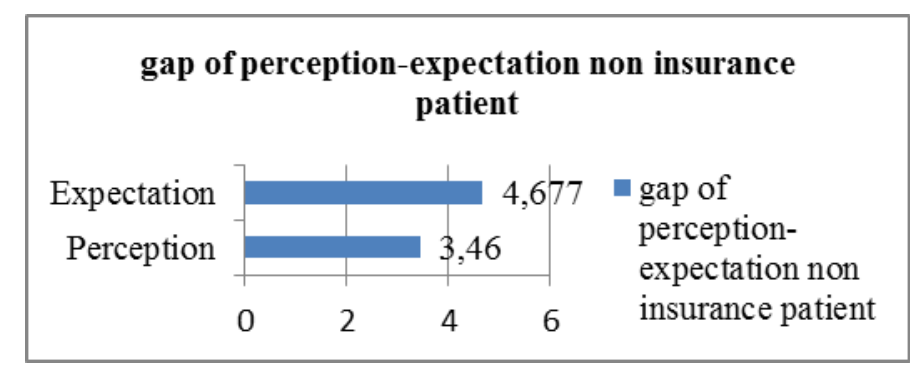

Figure 2. Gap of perception and expectation of non insurance patient

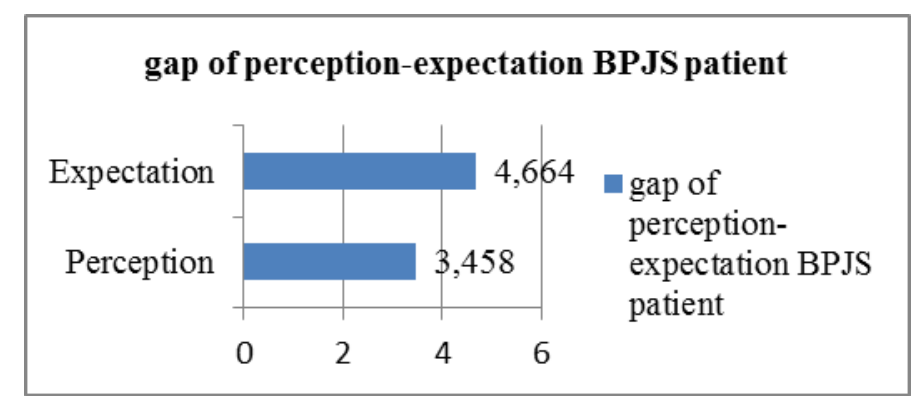

Figure 3. Gap of perception and expectation of BPJS health insurance patient

Figure 2 informs that at non insurance patient, the average perception of all service dimention is 3.460 , while the expectation is 4.677 . It creates a gap or the number of satisfaction level is $3,460-4,677=-$ 1,217 In the satisfaction classification, this gap is included into low classification. It means that the non insurance patient feels that health service in Negara public hospital doesn't fulfill their expectation.

At BPJS health insurance patient (Figure 3), the average perception of all service dimention is 3.458 , while the expectation is 4,664 . It creates gap or satisfaction level $3,458-4,664=-1,206$ In the satisfaction clasification this gap is included into low classification.it means that the service in Negara public hospital doesn't fulfill the BPJS health insurance patient's expectation. If it is compared with similar research, it is seen the average work of all service dimention is 3.81 , while the expectation is 4.37 . therefore, they create gap or satisfaction level $3.81-4.37=-0.56$. in the satisfaction classification, this gap is included into moderate classification. It means that the service in Depok I community health centers in Sleman Yogyakarta is moderate [8].

Patient's satisfaction is a subjective matter which is difficult to be measured, change rapidly, and there are many influencing factors. The subjectivity can be decreased and even it can be objective if there are adequate people have similar opinion about something. ${ }^{9}$ At the hospital service, the huge number of employees will get an attention, because it will influence patient's satisfaction, in this case doctor and nurse. Even the presence of nurse's service have the biggest service proportion at the hospital. Therefore, without ignoring the service of other employees, the service of doctor and nurse are exactly the service that must get a bigger attention from hospital management [9]. 


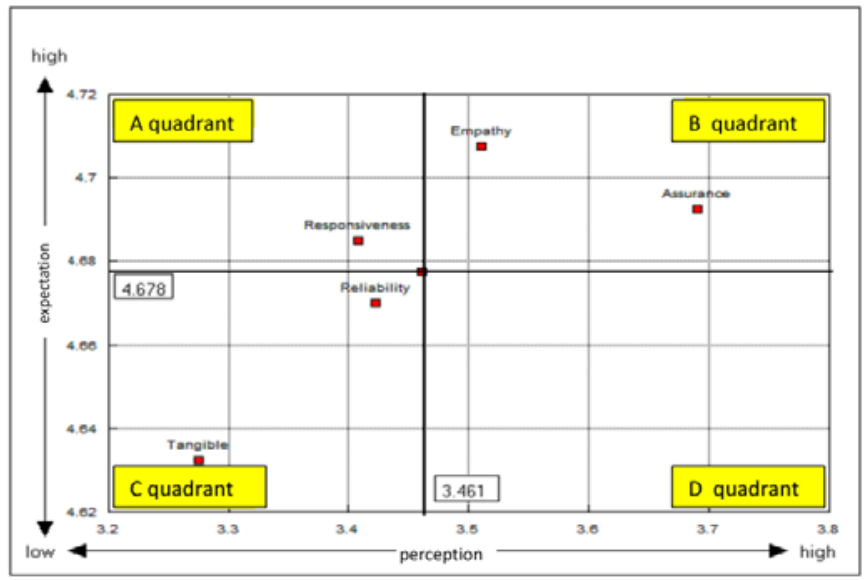

Figure 4. Kartesius Diagram of non insurance patient

Figure 4 describes that a quadrant on non insurance patient is Responsiveness dimention that must be the priority and fixed since it has high number of expectation for the patient, but unfortunately the working result is not satisfying. B quadrant on non insurance patient are Assurance and Emphaty dimentions, that must be kept since it loads important and proper factors that result high satisfaction level. C quadrant on non insurance patient are Tangible and Reliability dimentions that are considered not really importand by the patient, while the fact is the working result is not really special. D quadrant on non insurance patient doesn't have any attributes belong to it.

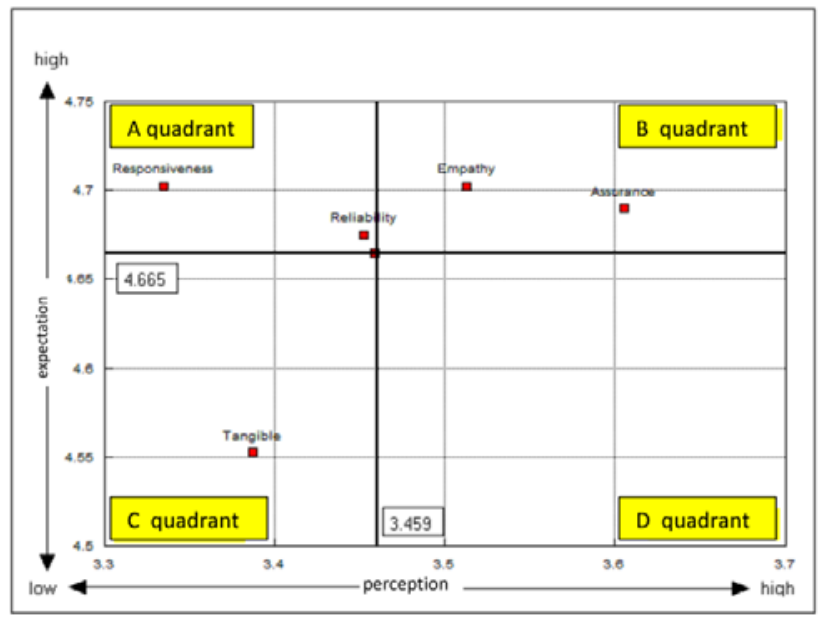

Figure 5. Kartesius diagram of BPJS health insurance patient

A quadrant on BPJS health insurance patient (Figure 5) has Responsiveness and Reliability dimentions that must become more priority and fixed, because it has high expectation value for the patient, but its working result is not satisfying. B quadrant on BPJS health insurance patient has Assurance and Emphaty dimentions, which must be kept because it loads important and appropriate factors; therefore the satisfaction level is higher. $\mathrm{C}$ quadrant on BPJS health insurance patient has Tangible dimention which is considered unimportant by the patient and the fact that its working result is not really special. D quadrant on BPJS health insurance doesn't have any attributes belong to it. 


\section{CONCLUSION}

Based on the research result, it shows that there is no significant difference of satisfaction between BPJS health insurance patient and non insurance patient toward health service in Negara Public Hospital.The biggest satisfaction on non insurance patient is at Assuerance variable ( $-1,002)$ and the smallest satisfaction is at Tangibles variable $(-1,357)$. The biggest satisfaction on BPJS health insurance patient is at Assuerance variable $(-1,085)$ and the smallest satisfaction is at Responsiveness variable $(-1,367)$.

Accorrding to the service dimension gap analysis, generally non insurance patient or BPJS health insurance patient are included into low classification which means that the service at Negara public hospital is still far from the patient's expectation. Based on the Importance performance analysis on non insurance patient, it is acquired attribute result Responsivenes that must be the priority and fixed. While on BPJS health insurance patient, it is acquired the attribute result Responsiveness and Reliability that must be the priority and fixed at Negara public hospital. Negara Public Hospital needs to improve the service quality on the variables which have low values or which still far from patient's expectation.

\section{ACKNOWLEDGEMENTS}

Author would like to thanks for dr. Made Dwipayana, MPPM as director for the permits to hold the research at Negara General Hospital, Jembrana, Bali, Indonesia.

\section{REFERENCES}

[1] UCLA \& NBER, "health behavior in developing countries", Prepared for the annual review of economics, vol. 3, 2011.

[2] Hasbullah T., "Politics of national health insurance of Indonesia: A New Era of Universal Coverage", presented at the $7^{\text {th }}$ European conference on health economics, July 23-26, 2008.

[3] Dorjsuren B., "Current challenges in delivering social security health insurance", ISSA meeting of directors of social security organizations in Asia and the pacific, 9-11 November 2005.

[4] http://www.depkes.go.id/resources/download/jkn/buku-pegangan-sosialisasi-jkn.pdf. downloaded on 13 May, 2015.

[5] Yousef HA., Mohamed IA., "Patients' Satisfaction with Medical Services in the Qassim Area", Journal of Clinical and Diagnostic Research, vol/issue: 5(4), pp. 813-817, 2011.

[6] Seema M., "Service quality as predictor of patient satisfaction", Journal of health management, vol/issue: 13(2), 2011.

[7] Ryantisari, NLA., Pascawati, NA., Muflih, "Perbedaan Tingkat Kepuasan Pasien Pengguna Askes Dan Pasien Umum Dalam Menerima Kualitas Pelayanan Keperawatan Di Instalansi Rawat Inap Kelas II RSUD Panembahan Senopati Kabupaten Bantul", Universitas Respati Yogyakarta, Yogyakarta, 2011.

[8] Rahmulyono, A., "Analisis Pengaruh Kualitas Pelayanan Terhadap Kepuasan Pasien Puskesmas depok 1 Di Sleman", Universitas Islam Indonesia, Yogyakarta, 2008.

[9] Christiwardani S., "Kepuasan Pasien Rumah Sakit (Tinjauan Teoritis dan Penerapannya Pada Penelitian)", Universitas Diponegoro, Semarang Jawa Tengah, 2004.

\section{BIOGRAPHIES OF AUTHORS}

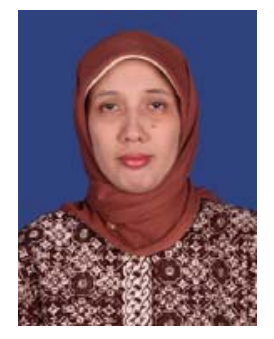

Arlina Dewi earned his bachelor's degree from department of medical faculty, Universitas Diponegoro Semarang in 1994. Then continued her master's degree of magister hospital management at Gadjah Mada University in Yogyakarta, and doctor's program at the same university. Until now, she was working at Universitas Muhammadiyah Yogyakarta as a lecture. She can be reach through dewikoen@yahoo.com

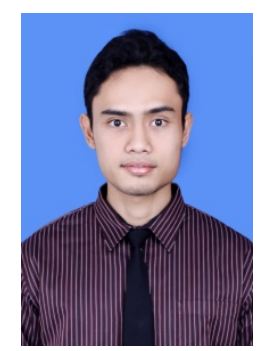

Naufal Kurnia Ramadhan earned his bachelor's degree from department of medical faculty, Muhammadiyah Yogyakarta University in 2010. Then continued his master's degree of magister hospital management at the same university. After his bachelor graduation until now, he was working at hospital in Negara, Jembrana, Bali as general practitioner. He can be reach through naufalkurnia@yahoo.com 